\title{
Risk Taking nd Survival of Small and Medium Scale Enterprises in Nigeria
}

\author{
Edwinah Amah \\ Department of Management, Faculty of Management Sciences \\ University of Port Harcourt, Nigeria. \\ Thomas Okoisama \\ Department of Management, Faculty of Management Sciences \\ University of Port Harcourt, Nigeria.
}

\begin{abstract}
The study investigated the relationship between risk-taking and the survival of small and medium scale enterprises in Port Harcourt. The cross sectional survey method was adopted. A sample size of eighty was drawn from a population of one hundred employees using the Taro Yamane formula. The questionnaire was the main instrument for data collection and data obtained was analysed using the SPSS. Spearman's rank correlation coefficient was used to test the hypotheses. Our findings revealed a strong and positive relationship between risk-taking and the measures of organizational survival. We concluded that risk-taking ability might proportionately predict the organizational performance and success level of a firm. We recommended that due to the complacent level in risk taking as discovered in the study, government should provide current statistics to enable small and medium scaled industries take calculated risk. It will be necessary that firms be given soft loans by banks to enable them undertake more innovative and enterprising activities. Government ought to as matter of criticality help planned business visionaries to have admittance to the public purse to back them up. This could enable them identify business opportunities and take the risk of embarking on them.
\end{abstract}

Key words: Risk-taking, survival, small scale enterprise, medium scale enterprise.

\section{INTRODUCTION}

Overtime, it has been observed that Small and Medium-scale Enterprises (SMEs) play critical roles in the process of industrialization and sustainable Organizational Survival as it has enabled entrepreneurship activities through which employments have been generated and poverty reduction and sustainable livelihood achieved (Ikem et al., 2012), The existence of small and medium enterprises (SMEs) is so unique to the nation and that is why sometimes, they are described as engine of growth of most economies of the world (Ibrahim, 2015). However, the take off and efficient performance of any industrial enterprise, be it small or large, will require a sound accounting technique, tools and system.

Taylor (2013) found that SMEs managers that are willing to take risk are more likely to achieve higher performance and growth irrespective of the business environment in which they operate. Keh, Nguyen, and $\mathrm{Ng}$ (2007) in their study found that risk taking has influential role on information acquisition and utilization of marketing information for their competitive capacity that led to high organizational performance and success.

Lyon et al., (2000) and Nowduri et al., (2002) assert that SMEs facilitate easy distribution of economic wealth and the decentralization of economic growth. Conversely, despite the contributions of these SMEs to national development they are responsible for most of the 
breakthroughs and advances in new products and process. They contribute to the alleviation of poverty through employment creation, equitable distribution of wealth, provision of flexible and specialized service to large scale industries, stimulation of economic development and national growth by participating mostly in the untapped markets. However, SMEs and their impacts have been less satisfactory and their performances have fallen short of expectation particularly in the developing economies of the world (Manbula, 2002).

Over the past decade, much has been written about risk taking and organizational survival. Despite the increase in prior publications and studies, the extent to which entrepreneurial behaviors such as risk taking influence organizational survival has not been sufficiently clarified (Zahra and Covin, 1995). The study specifically examined the relationship between risk taking and organizational survival in selected SMEs in Rivers State.

\section{Objective of the Study}

1. To investigate the relationship between risk taking and organizational survival in selected SMEs in Rivers State.

\section{Research Hypotheses}

Ho1: There is no significant relationship between risk taking and customer satisfaction of SMEs in Rivers State.

$\mathrm{Ho}_{2}$ : There is no significant relationship between risk taking and adaptability of SMEs in Rivers State

\section{Risk-taking}

\section{REVIEW OF RELATED LITERATURE}

Lumpkin and Dess (1996) considered risk-taking as management decision-making process that accept the willingness to undertake uncertainty, and seize opportunities in the market place by committing large resources with the expectation to achieve high returns on investment. Risk taking represents a willingness to withstand uncertainty and mistakes as one explores new ideas, advocates unconventional or unpopular positions, or tackles extremely challenging problems without obvious solutions, in order to increase the likelihood of accomplishment (Neves and Eisenberger, 2014).

The concept risk is not sufficiently defined in the literatures of entrepreneurship and management theories. It is a concept whose meaning differs according to the different authors and in the context in which it is used. Mitchel (1995) submitted that embarking on any new ventures, start-ups etc. involve risk, or the possibility that actual result may differ from expectation and that uncertainty is the source of risk, for if there had been no uncertainty, there would also be no risk. Risk according to Dhliwayo and Vuuren,(2007) is an important element of the strategic entrepreneurial attitude that involving creativity, innovation and capturing opportunities that leads to organizational wealth creation and organizational survival. Lewin and Stephen (1995) studied risk-taking propensity in organizations and indicated that risk-taking propensity is the degree to which individual organizations exhibit, support and willingness to make risky commitments of resources and funds across situation of uncertainty for the purpose of capturing opportunities. Too little and too much risk taking are both dangerous for organizations' long-term welfare (Wicks et al., 1999). The degree of optimal risk may vary substantially by job type and organization, making it a "conditional good" (Molina-Morales et al., 2011, p. 118) risk taking has major implications for employee and organizational outcomes and is therefore an important topic to study. 


\section{The Concept of Organizational Survival}

Maheshwari (1980) argued that the concept of Organizational survival is a multiple dimensional concept with no common definition, making it elusive that there is no one single way of defining organizational survival. This fact may be due to the many criteria used to measure organizational survival and the many definitions available for the concept. He further defined success as the ability of an organization to achieve an acceptable outputs and expectations which are in line with the organizational goals and objectives. Evidence found in the entrepreneurial, management and business literatures confirmed that organizational survival and organizational performance are very narrowly connected (Perren, 2000; Jennings and Beaver, 1992). Also, according to De-smet et al, (2006) success can be defined as an organizational ability to operate effectively and efficiently, coping adequately and being able to withstand the environmental turbulences by being flexible and adapting to change which may result to growth. Imoisili (1978) defined Organizational survival as organization's ability to achieve sustainable growth and realization of its goals which leads to eventual superior performance. Similarly, Beaver and Jenning (1995) are of the view that the most commonly adopted description of organizational survival has much to do with financial viability and growth with sufficient profits than other factors such as owner's satisfaction, employee satisfaction etc. Simpson et al., (2007) maintained that organizational survival is a multidimensional concept which has no single significant element as its measures of analysis. Simpson et al., (2004) noted that there are two major indicators of success: the financial and non-financial measures. The financial performance measures of organizational survival includes: profitability, returns on capital, productivity of assets, sales margins, net operating margin etc. while the non-financial indicators are the degree of employee satisfaction, ability to retain management talent, the degree of customer satisfaction, owners' satisfaction, superior products and services etc. On the other hand, determination of the right criteria is paramount in getting the accurate result. According to Masuo (2001) to avoid errors in determining the measures, the selections of appropriate measure should depend on the type or nature of the organization under review, the various environmental factors, cultures, management styles, capital availability, technology and goal of the organization should be considered. This argument is based on the fact that every organization has its different characteristics, goals and constituencies. Paige and Littrell (2002) assert that some scholars includes subjective (intrinsic) criteria such as freedom and independence, being one's own boss, controlling one's own future; while the objective (extrinsic) factors such as increase profitability and wealth as the criteria for organizational survival. Cameron (1979) suggested that there are other criteria that could be used in the measurement of organizational survival such as effectiveness and efficiency. Organizational survival will be defined as the ability of a firm to realize and actualize its outcome and expectations in line with its mission, goals and objectives

\section{Risk Taking and Organizational Survival}

Murugesan \& Jayavelu, (2017) suggested that optimistic entrepreneurs (those he referred to as risk takers) will have a better chance at survival than the pessimistic ones. This was a view strongly shared by Parimala \& Ilham (2016) who also revealed a strong and significant relationship between innovativeness, risk taking and customer satisfaction and adaptability. They suggested a good blend of these would position an entrepreneur in a better position to survive. According to Neves, and Eisenberger, (2014), risk attitudes have an impact on not only the decision to become an entrepreneur but also the survival and failure rates of entrepreneurs. Their empirical results confirm that persons whose risk attitudes are in the medium range survive significantly longer as entrepreneurs than do persons with particularly low or high risks. Ebiringa (2012) and Adegbite, Ilori and Abereijo (2007) also asserted that risk taking significantly and proportionately predicts the organizational performance and success level of a firm. 


\section{RESEARCH METHODOLOGY}

The study adopted a cross-sectional survey of the quasi-experimental design. This method is adopted because the respondents who are in their private business are exposed to complex relationships which are not subject to manipulation (Baridam, 2001). This study aimed at examining the relationship between Risk-taking and organizational survival in SMEs in Rivers State. The population for this study comprises of all the Small and Medium Scale Enterprises in Rivers State, registered with the Rivers State Ministry of Trade and Commerce. However, for easy accessibility, the accessible population consists of 120 respondents, (owners-partners, managers and key officers) from the 20 selected SMEs within Rivers State, using purposive sampling technique. It is assumed that responses obtained from the sample respondent would be representative of the opinions of all SMEs operating in Rivers State. The respondents are in position to express their opinion about the questions relating to the research instrument. The sampling procedure adopted in this study is the Simple random sampling techniques. This approach is to enable each member of the population to have an equal chance of being selected. A sample size of eighty (80) owners-partners, managers and key officers was drawn from the twenty (20) selected SMEs under review. The sample size was determined using the sample size determination formula of Taro Yamens formula at 0.05 level of significance (Baridam, 2008)

\section{Test of Hypotheses}

\section{RESULTS AND DISCUSSION RESEARCH RESULTS AND FINDINGS}

\section{Hypothesis one}

Ho1: There is no significant relationship between risk taking and customer satisfaction of SMEs in Rivers State.

Table 4.1. Correlation Output of risk taking and customer satisfaction of SMEs in Rivers State. Correlations

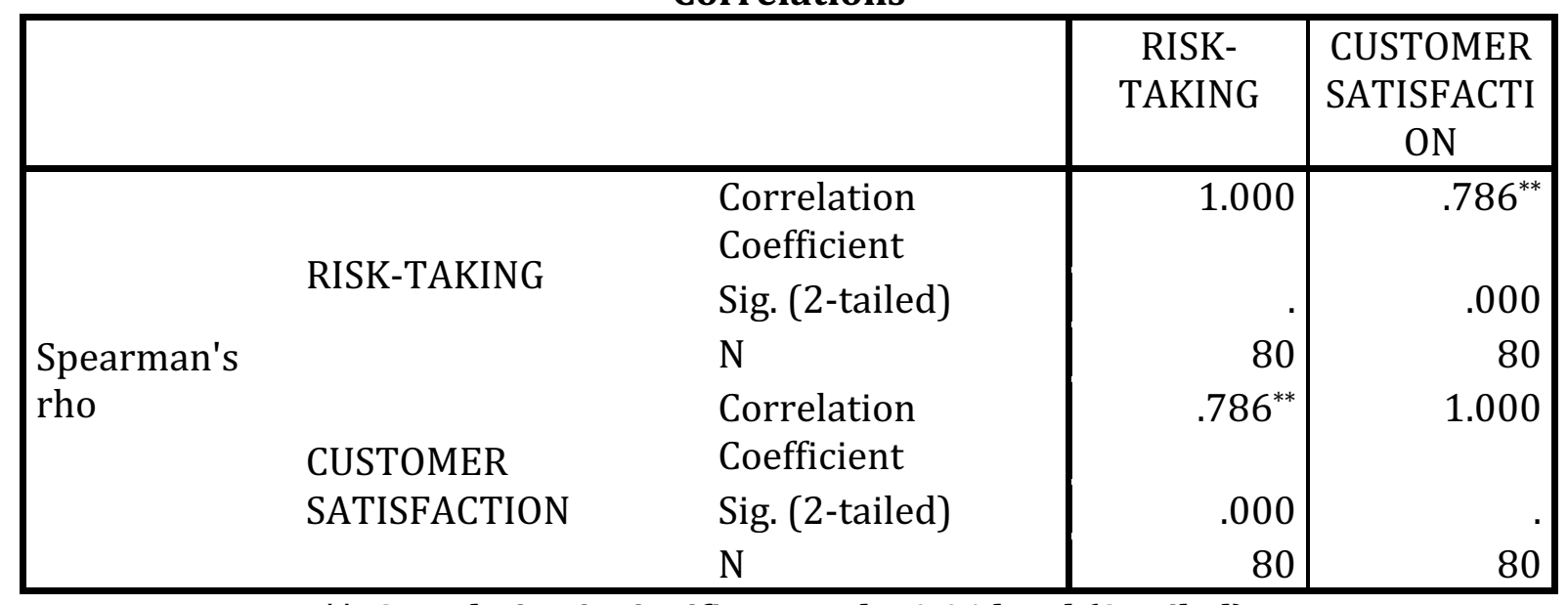

**. Correlation is significant at the 0.01 level (2-tailed).

Source: Statistical Package for Social Sciences (version 22) Extract.

\section{Hypothesis Two}

Ho2: There is no significant relationship between risk taking and Adaptability of SMEs in Rivers State. 
Table 4.2. Correlation Output of risk taking and Adaptability of SMEs in Rivers State. Correlations

\begin{tabular}{|c|c|c|c|c|}
\hline & & & RISK-TAKING & $\begin{array}{c}\text { ADAPTABILIT } \\
\mathrm{Y}\end{array}$ \\
\hline \multirow{6}{*}{ Spearman's rho } & \multirow{3}{*}{ RISK-TAKING } & Correlation Coefficient & 1.000 & $.727^{* *}$ \\
\hline & & Sig. (2-tailed) & & .000 \\
\hline & & $\mathrm{N}$ & 80 & 80 \\
\hline & \multirow{3}{*}{ ADAPTABILITY } & Correlation Coefficient & $.727^{* *}$ & 1.000 \\
\hline & & Sig. (2-tailed) & .000 & \\
\hline & & $\mathrm{N}$ & 80 & 80 \\
\hline
\end{tabular}

**. Correlation is significant at the 0.01 level (2-tailed).

Source: Statistical Package for Social Sciences (version 22) Extract.

Hypothesis One: Relationship between Risk-taking and Customer Satisfaction- The Table 4.1 above illustrates the analysis for the association between Risk-taking and customer satisfaction of SMEs in Rivers State where Rho $=.786$ and $p=0.000$. The findings shows a very positive and significant association between both variables.. This means that increase in Risktaking is associated with increase in Customer Satisfaction. Hypothesis Two: Relationship between Risk-taking and Adaptability- Table 4.2 above illustrates the analysis for the association between Risk-taking and Adaptability of SMEs in Rivers State where Rho $=.727$ and $\mathrm{p}=0.000$. The findings show a very positive and significant association between both variables. There is a significant relationship between Risk-taking and Adaptability of SMEs in Port Harcourt. This implies that increase in Risk-taking is associated with increase in Adaptability.

\section{Risk taking: Customer Service and Adaptability}

\section{DISCUSSION OF FINDINGS}

In hypotheses one, our findings here showed a significant relationship between risk taking and customer satisfaction this is in line with the revelation of the (Murugesan \& Jayavelu, 2017) who suggested that optimistic entrepreneurs (those he referred to as risk takers) will have a better chance at survival than the pessimistic ones. This was a view strongly shared by Parimala \& Ilham (2016) who also revealed a strong and significant relationship between innovativeness, risk taking and customer satisfaction and adaptability. They suggested a good blend of these would position an entrepreneur in a better position to survive. The findings is also in line with Neves, and Eisenberger, (2014), who asserted that risk attitudes have an impact on not only the decision to become an entrepreneur but also the survival and failure rates of entrepreneurs

Results on hypotheses two revealed a significant relationship between risk taking and adaptability. It was revealed that entrepreneurs who are more willing to take risk will have a better chance and will find it easier to adopt changes that will help them manipulate and adapt to changes in the environment as also agreed by (Ebiringa, 2012) who suggested that risk taking could be a deciding factor on how easily an entrepreneur adapt to changes. This suggestion was also echoed by (Chononye et. al., 2016) who also advocated that entreprenures should be proactive and take more risk however he suggested they take more careful and articulated risk.

\section{SUMMARY, CONCLUSION AND RECOMMENDATIONS}

This paper concludes by fully agreeing with Ebiringa (2012) and Adegbite, Ilori and Abereijo 
(2007) who asserted that risk taking significantly and proportionately predicts the organizational performance and success level of a firm. In light of the above, the study recommends that due to the complacent level in risk taking as discovered in the study, it will be necessary that firms be given proper finance by banks to enable them undertake more innovative and enterprising activities.

\section{References}

Adegbite, S. A., Ilori, M. O. Irefin, I. A. Abereijo, I. O and Aderemi, H. O. S. (2007), "Evaluation of the Impact of Entrepreneurial Characteristics on the Performance of Small Scale Manufacturing Industries in Nigeria", Journal of Asia Entrepreneurial and Sustainability",vol 111, Issue 1

Amah, E (2006) Human Resource Management. Amethyst Publishers Port Harcourt.

Amah, E (2012) Corporate Culture and Organizational Effectiveness. A Study of the Nigerian Banking Industry. European Journal of Business and Management 4, (8)

Antoncic, B., \&Hisrich, R.D. (2001).“Clarifying the Entrepreneurship Concept”. Journal of Small BusiessEntrepreneurship and Development, 10(1), 7-24.

Ariyo, D. (2008). Small firms as the back bone of the Nigerian economy. Retrieved on $15^{\text {th }}$ Jan $\backslash 2017$

Ayyagari, M., Beck, T., and Demirgic. (2003). Small and Medium Enterprises Across the Globe: A New Database of World Bank Policy Research Working Paper. No 3127, 1-34.

Baridam, D.M. (2008). "Research Methods in Administrative Sciences, $3^{\text {rd }}$ edition, Port Harcourt." Sherlrook Associates, Port Harcourt.

Caliendo, M. Fossen, F and Kritikos, A (2008) The Impact of Risk Attitudes on Entrepreneurial Survival IZA Discussion Paper No. 3525

Chinonye, L. M., Maxwell, A. O., Mosunmola, A. Mayowa, A, \& Fred, I. (2016) entrepreneurship education and entrepreneurial intentions; the moderating role of passion, The social science, 11 (5) 645-653

Covin, J.G. \& Slevin D.P. (1989). "A Conceptual Model of Entrepreneurship as a firm behavior”. Entrepreneurship Theory and Practice, 16(1), 7-25.

Covin, J.G. \& Slevin D.P. (2006). Strategic Process Effects on the Entrepreneurial orientation-sale rate relationships. Academy of Management Journal 6

Damanpour, F. (1991). Organizational Innovation: A meta-analysis of effects of determinant and moderator: Academy of Management Journal. 34(3): 555-590.

De-Smet \& Schaninger, W. (2006). Performance and Health: in search of sustainable excellence. New York, Mckensey and company

Dhliwayo,\&Vuunen (2007). The strategic entrepreneurial thing imperative. Actacom (7), 123-134.

Ebiringa, Thaddeus (2012). Perspectives: Entrepreneurship Development \& Growth of Enterprises in Nigeria. Entrepreneurial Practice Review, 2(2), 75-92.

Hult, G.TM. Harley, R.F. and Knight G.A. (2004). Innovativeness: Its Antecedents and impact on business performance industrial marketing management 33(5): 429-438.

Imoisili, C.I. (1978). "Key Success Factors in Multinational and Indigenous Companies in Nigeria: A comparative Analysis" Columbia Journals of Sociology .

Mill, J. S (1848). Principles of Political Economy with Some Applications to Philosophy, London, John W. Parker.

Knight, C. (1997). “A Cross-Cultural Reliability and Validity of a Scale to Measure Firm Entrepreneurial Orientation". Journal of Business Venturing, 12, (3)

Kothari, C.R. (2004). Research Methodology Method and Technique (3rd Ed) New Delhi, New age International. Kotler, P. \& Kevin, K. (2009). Marketing management,(13 th Edi). New Jersey, Pearson Edu. Inc. Upper Saddle River.

Kuratko, D.F. et al (2009). "Managing Corporate Entrepreneurial: Examining perception and position" Journals of Business Venturing, 24(3). 
Kuratko, D. F. 2005. The emergence of entrepreneurship education: Development, trends, and challenges. Entrepreneurship Theory and Practice, 29, 577-597.

Lumpkin, T. \& Dess, G.G (1996). "Clarifying the Orientation Construct and linking with it to performance." Academy of Management Review, 21.

Lumpkin, T. \& Dess, G.G. (2001).“Linking Two Dimensions of Entrepreneurial Orientation to Firm Performance”. The Moderating

Lumpkin, T. \& Dess, G.G. (2004.: “Entrepreneurial Orientation as Service of Innovative Strategy”, Blackwell, Oxford.

Lyon, D. W., G. T. Lumpkin and G.G. Dess (2000). Enhancing entrepreneurial orientation research: operationalization and measuring a key strategic decision making and process. Journal of Management 26 (5) $1055-1085$

Maheshwari, B.I. (1980). Decision Styles and organizational Effectiveness. New Vickas Publishing House. PVT LTD. Masuo, D., at al (2001). Factors Associated with Business Success: A Comparison of Single Manager and Dual Manager Family Business. Journal of family economic, 22(1).

Mcgrath, G. \& Macmillan (2000). “The Entrepreneurial attitude: Strategies for Continuously Creating Opportunity in Age of Uncertainty," Harvard Business School Press, Boston.

Molina-Morales, F.X., Martınez-Fernandez, M.T. and Torlo, V.J. (2011), "The dark side of trust: the benefits, costs and optimal levels of trust for innovation performance", Long Range Planning 44, 118-133

Morris, M.H. and Kuratko, D.F. (2002). Corporate entrepreneurship mason. OH: Thomson. South-Western.

Murphy, G.B., Trailer, J.W. and Hill, R.C. (1996). Measuring Performance in Entrepreneurship research. Journal of Business Research, 36(1) 15-33.

Muhammad, K. Y. Nadeem A. M., S. A. \& Muhammad U. K. (2015) Impact of Entrepreneurship Education on Attitudes of Students towards Entrepreneurship, Journal of Basic \& Applied Sciences, 11, 590-595

Murugesan, R. \& Jayavelu, R. (2017) The influence of big five personality traits and self efficacy on entrepreneurial intentions: the role of gender, Journal of entrepreneurship and innovation in emerging economies, 3 (1) 66 - 89

Neves, P. and Eisenberger, R (2014),"Perceived organizational support and risk taking", Journal of Managerial Psychology, 29 (2) 187 - 205

Ngek, B.N. (2012). "An Exploratory Study on Entrepreneurial attitude in the Small and Medium Enterprise (SME) success": African Journal of Business Management 6 (9), 3364-3372

Nowduri, S. (2012). Frame work for sustainability of entrepreneurship for SME's in emerging economy. World Journal of Management, 4. 51-66.

Okpara, F.O. (2000). Entrepreneurship: Text and Cases. Enugu: Precision Printer and Publishers.

Okpara, J.O. (2009). Strategic choices Export orientation and export performance of SME's in Nigeria. Journal of Business Research, 47(8) 1281-1299.

Parimala, R. Ilham, S. (2016) The effectiveness of entrepreneurship education in developing entrepreneurial intentions among malaysian university students: (a research findings on the structural equation modeling), European Journal of Business and Social Sciences. 5, (02), 30 - 43

Rauch, A. Wiklund, Lumpkin, G.T. and Frese, m. (2009). Entrepreneurial orientation and business performance: An assessment of past research and suggestion for future entrepreneurship, theory and practice, 33(33) 761-789.

Rauch, A., Wiklund, J., Frese, M. \& Lumpkin, T.G. (2004). Entrepreneurial Orientation and Business Performance: An assessment of past research and suggestion for the future. Cumulative Empirical Evidence: entrepreneurship theory and practice, 33(1)761-789

Schumpeter, J.A. et al (1934). "The Theory of economics. University Press.

Schumpter, J.A. (1934). The theory of economy development: An inquiry into profits, capital, credit, interest and business cycles Cambridge: Harvard University Press.

Senges, M. (2007) 'The fifth discipline: The Art and Practice of the Learning Organization. New York: CurrencyDoubleday.

Simon, A., Kumar, K., Sheeman, M., and Offat. P.P. (2011). Strategic capabilities and other relationship to organizational survival and its measures: Some pointer from Australian studies, Management decision. 49 (8) 


\section{5-1320.}

Taylor, P. (2013). The effects of entrepreneurship orientation on the internalization of SMEs in developing countries. African Journal of Business Management 7 (19) 1927-1937

Thompson, J.L. (2004). “Innovation Through People. Management decision”, 42(9), 1082-94.

Tidd, J. \& Bassant, J. (2009). Managing Innovation: Integrating Technology, Market and Organizational Change,4th edition, Chichecter.

Timmons, A. \& Spinelli, S. (2004). "New Venture Creation: Entrepreneurship for the $21^{\text {st }}$ Century. $6^{\text {th }}$ Edition, McGraw-Hill, New York.

Veldsman T.H. (1982). Towards an Integrated View of the Concept, "Organizational Effectiveness Cube". Psychologia Africana. 21

Venkataraman, S. (1989). "The Distinctive Domain of Entrepreneurship research. Advance in entrepreneurship firm emergence and growth". JAI Press: Greenwick, CT.

Wicks, A.C., Berman, S.L. and Jones, T.M. (1999), "Toward a conception of optimal trust: moral and strategic implications", Academy of Management Review, 24, 99-116.

Zahra, A. (2011). An Empirical study on the causes of business failure in Tvanian context. African Journal of Business Management. 5 (17) 1488-7498.

Zahra, S.A. \& Covin (1995). “Contextual influences on the corporate entrepreneurship - performance relationship". A Longitudinal Analysis, Journal of Business Ventures, 10(1), 43-59.

Zahra, S.A. (1991). "Predictor and Financial Outcomes of Corporate Entrepreneurship". Exploratory Study Journal of Business Venturing. (6), 259-285.

Zahra, S.A. (2000). International Corporate Entrepreneurship and Firm Performance: The Moderating Effect Of International Environmental Hostility. Journal of business venturing 15(5). 